\title{
Pengembangan Perangkat Pembelajaran Fisika Berbasis Proyek untuk Meningkatkan Kemampuan Komunikasi Peserta Didik
}

\author{
Wiwik Karuniawati*, Ahmad Harjono, Gunawan, Ahmad Busyairi, Muhammad Taufik \\ Program Studi Pendidikan Fisika, Universitas Mataram \\ *Email: karuniawatiwiwik99@gmail.com
}

Received: 9 November 2021; Accepted: 7 Desember 2021； Published: 15 Desember 2021 DOI: http://dx.doi.org/10.29303/jpft.v7i2.3096

\begin{abstract}
This study aims to determine the feasibility of project-based learning tools to improve students' communication skills. The design used is Research and Development $(R \& D)$ with a $4 D$ model (define, design, develop, \& disseminate). This research is only limited to the develop stage, namely validation by six expert validators with supporting data in the form of physics education student responses to the learning tools developed. The learning tools developed include the syllabus, lesson plans, LKPD, and observation sheet instruments. The results of the study based on expert validation showed that the learning tools developed had very valid criteria on the syllabus, lesson plans, LKPD, and observation sheet instruments. The average result of the calculation of student responses is $99 \%$. Based on the results of these studies, it can be concluded that project-based learning tools are feasible to use in the physics learning process to improve students' communication skills.
\end{abstract}

Keywords: Development of Learning Tools; Project; Communication Skill

\section{PENDAHULUAN}

Fisika merupakan salah satu cabang dari ilmu pengetahuan alam (IPA). IPA termasuk bagian dari ilmu sains yang mencakup proses, produk, dan sikap. Arti sains sebagai sebuah proses adalah bagaimana cara memperoleh ilmu pengetahuan. Pengetahuan fisika diperoleh melalui serangkaian proses ilmiah seperti melakukan pengukuran, percobaan, dan diskusi serta melibatkan peserta didik secara langsung dalam kegiatan sehingga akan membantu pemahaman terhadap konsepkonsep yang ada (Gunawan, 2015). Proses memproleh ilmu pengetahuan juga ditekankan agar peserta didik mampu mengkomunikasikan konsep yang dipahami menggunakan bahasa dan pemahamannya sendiri.

Komunikasi merupakan proses usaha untuk memberikan suatu pengertian dengan cara memindahkan pesan dari seseorang terhadap orang lain, yang dilakukan secara lisan maupun tulisan dengan tujuan untuk dimengerti oleh kedua belah pihak
(Wirawan \& Mubarak, 2014). Komunikasi merupakan hal yang tidak bisa dipisahkan dalam proses pembelajaran, karena akibat adanya komunikasi proses pembelajaran dapat berlangsung. Komunikasi berlangsung ketika adanya interaksi antar peserta didik dengan guru, atau sesama peserta didik. Kemampuan komunikasi dibagi menjadi 2 yaitu lisan dan tulisan.

Kemampuan komunikasi lisan merupakan kemampuan seseorang dalam menyampaikan ide atau gagasan yang telah diperolehnya dari kegiatan pengematan secraa langsung melalui kegiatan presentasi (Lestari et al. 2016). Sedangkan kemampuan tulisan merupakan kemampuan seseorang dalam menuangkan hasil yang diperoleh menjadi sebuah laporan dari proses pengamatan dan percobaan.

Kemampuan komunikasi individu Indonesia masih tergolong rendah. Permasalahan ini sejalan dengan pernyataan dari Munandar bahwa pendidikan di Indonesia lebih menekankan pada hafalan dan mencari satu jawaban yang benar 
terhadap soal-soal yang diberikan sehingga proses pemikiran tinggi termasuk berpikir kreatif dan kemampuan berkomunikasi jarang dilatih (Nugroho et al. 2019). Hal ini menjadi sebuah tantangan bagi pendidikan di Indonesia terutama pada abad ke 21 karena kemampuan komunikasi merupakan salah satu kemampuan yang harus dimiliki oleh peserta didik. Pendidikan di Indonesia yang berkualitas tentu mengikuti perkembangan pada abad 21 salah satunya dengan mengubah kurikulum dari KTSP menjadi kurikulum 2013. Perubahan kurikulum tentu akan berpengaruh juga terhadap perangkat pembelajaran yang dikembangkan atau digunakan.

Perangkat pembelajaran merupakan hal yang harus dimiliki oleh setiap guru sebagai panduan atau acuan dalam mengajar. Perangkat pembelajaran merupakan sarana penunjang pembelajaran yang berisi perencanaan pembelajaran yang menguraikan secara rinci tentang kompetensi yang akan dicapai peserta didik, rancangan pembelajaran yang mengikuti sintaks model pembelajaran tertentu, pedoman kegiatan bagi peserta didik dan alat untuk mengukur ketercapaian kompetensi peserta didik (Kusumaningrum \& Djukri, 2016).

Guru sebagai tenaga pendidik perlu merancang dan menyusun perangkat pembelajaran yang dapat melatih dan meningkatkan kemampuan komunikasi peserta didik. Ada banyak model, pendekatan, dan metode yang dapat digunakan untuk meningkatkan kemampuan komunikasi peserta didik dalam proses pembelajaran, salah satunya model yang direkomendasikan pada kurikulum 2013 adalah Project Based Learning (PjBL).

Model pembelajaran merupakan sebuah rancangan yang berisi gambaran proses pembelajaran yang dapat dilaksanakan oleh guru dalam mentransfer ilmu pengetahuan kepada peserta didik. Ada 3 model pembelajaran yang sesuai dengan pendekatan saintifik yaitu inkuiri, Problem Based Learning (PBL), dan Project Based Learning (PjBL). PjBL merupakan bentuk pembelajaran yang didasarkan pada temuan konstruktivis bahwa peserta didik mendapatkan pemahaman materi yang lebih dalam saat mereka secra aktif membangun pemahaman mereka dengan bekerja menggunakan gagasan (Sujana \& Sopandi, 2020).

Pembelajaran berbasis proyek yang dikembangkan merepresentasikan karakteristik dan kebutuhan peserta didik, yaitu pembelajaran yang dapat membuat pengetahuan fisika yang semula abstrak menjadi lebih mudah dicerna, dimana pada setiap kegiatan proyek yang dirancang dengan memperhatikan unsur sains dan kemampuan berkomunikasi (Wirawan \& Mubarak, 2014). Model pembelajaranberbasis proyek memiliki manfaat menurut Majid \& Chaerul (dalam Setyani et al. 2016) yakni meningkatkan motivasi belajar peserta didik, meningkatkan kemampuan pemecahan masalah, mendrong peserta didik untuk mengembangkan dan mempraktikkan keterampilan mengomunikasikan, membuat peserta didik lebih aktif dan berhasil memecahkan masalah yang kompleks.

Model pembelajaran berbasis proyek memiliki pengaruh terhadap peningkatan yang signifikan untuk kemampuan komunikasi peserta didik (Nugroho et al. 2019). Model pembelajaran berbasis proyek mampu meningkatkan kemampuan oral communication peserta didik menjadi $60 \%$ - 72,31 \% (Wahyuni et al. 2019). Hal ini diperkuat oleh hasil pemberian model pembelajaran berbasis proyek dapat meningkatkan kemampuan komunikasi (Lestari et al. 2016). 
Berdasarkan uraian di atas peneliti mengembangkan perangkat pembelajaran berbasis proyek untuk meningkatkan kemampuan komunikasi peserta didik yang divaliditas untuk mengetahui layak atau tidaknya digunakan dalam proses pembelajaran fisika.

\section{METODE PENELITIAN}

Penelitian dan pengembangan dilakukan menggunakan model 4D. Penelitian ini dibatasi sampai tahap pengembangan (develop). Tahap pendefinisian (define) dilakukan analisis awal, analisis kurikulum, analisis kemampuan peserta didik, dan analisis materi. Tahap perancangan (design) dilakukan rancangan isi dari silabus, RPP, LKPD, dan instrumen lembar observasi. Tahap pengembangan (develop) dilakukan pembuatan produk, validasi produk, revisi, dan memberikan angket respon kepada mahasiswa pendidikan fisika terhadap perangkat yang dikembangkan.

Data validitas diperoleh dari 6 validator ahli. Hasil validasi dan saran digunakan untuk merivisi perangkat pembelajaran yang dikembangkan. Validitas perangkat pembelajaran berbasis proyek dihitung menggunakan persamaan berikut:

$$
N A=\frac{\sum_{1}^{n} v_{n}}{n}
$$

Keterangan:

NA : rata-rata validitas

$\mathrm{V}_{\mathrm{n}} \quad$ : nilai validitas pakar ke-n

n : banyak pakar

kategori hasil perhitungan rata-rata nilai validitas dapat dilihat pada Tabel 1 (Ratumanan \& Laurens, 2011).

Tabel 1. Kriteria Penilaian Validitas

\begin{tabular}{lll}
\hline Rata-rata & Penilaian & Keputusan \\
\hline $3,26-4,00$ & Sangat Valid & Tanpa revisi \\
\hline $2,51-3,25$ & Valid & $\begin{array}{l}\text { Revisi } \\
\text { sesuai saran }\end{array}$
\end{tabular}

\begin{tabular}{lll}
\hline Rata-rata & Penilaian & Keputusan \\
\hline $1,76-3,25$ & Cukup Valid & Revisi \\
$1,00-1,75$ & Tidak Valid & Revisi total \\
\hline
\end{tabular}

Kevalidan perangkat pembelajaran yang dikembangkan minimal berada pada kategori valid sehingga layak digunakan dalam proses pembelajaran.

\section{HASIL DAN PEMBAHASAN}

Hasil analisis awal dan kemampuan peserta didik menunjukan bahwa pembelajaran fisika di dalam kelas masih berpusat pada guru sehingga kemampuan untuk mengkomunikasikan konsep yang bersifat abstrak masih kurang. Peserta didik membutuhkan inovasi pembelajaran melalui kegiatan proyek, dimana kegiatan ini melibatkan secara langsung peserta didik untuk menemukan dan memahami konsepkonsep fisika. Berdasarkan hal tersebut dikembangkan perangkat pembelajaran fisika berbasis proyek untuk meningkatkan kemampuan komunikasi peserta didik.

Analisis kurikulum dan materi dilakukan dengan memilih Kompetensi Inti (KI) dan Kompetensi Dasar (KD) yang dijadikan acuan untuk mengembangkan perangkat pembelajaran sesuai dengan kurikulum 2013. KD yang digunakan adalah KD 3.9 dan KD 4.9 materi usaha dan energi. Perancangan dilakukan untuk merancang silabus, RPP, LKPD, dan instrumen lembar observasi. Perangkat ini dikembangkan mengikuti tahapan atau sintaks model pembelajaran berbasis proyek.

Perangkat tersebut dinilai oleh 6 validator ahli. Data hasil penelitian dari validator ahli kemudian dianalisis untuk mengetahui perangkat pembelajaran yang dikembangkan valid atau tidak. Hasil validasi perangkat pembelajaran ditampilkan pada Tabel 2. 
Tabel 2. Hasil Validasi Perangkat Pembelajaran

\begin{tabular}{llrl}
\hline No. & Perangkat & $\begin{array}{c}\text { Rata }- \\
\text { rata }\end{array}$ & Kategori \\
\hline 1. & Silabus & 3.50 & Sangat valid \\
2. & RPP & 3.56 & Sangat valid \\
3. & LKPD & 3.43 & Sangat valid \\
4. & Instrumen & 3.50 & Sangat valid \\
& Lembar & & \\
& Observasi & & \\
\hline
\end{tabular}

Hasil validasi pada Tabel 2 menunjukan bahwa silabus layak digunakan sebagai panduan dalam penyusunan RPP dengan model pembelajaran berbasis proyek dan perangkat pembelajaran lainnya dengan beberapa revisi dari validator ahli. Revisi dari validator ahli yakni menyesuaikan cara atau metode pembelajaran dengan sintaks PjBL, menyesuaikan waktu dan kegiatan proyeknya, memperbaiki format tabel, dan memunculkan indikator kemampuan komunikasi dalam kegaiatan pembelajaran, menyederhanakan kalimat yang digunakan, memisahkan komponen pengetahuan dan keterampilan.

Pada Tabel 2 menunjukan bahwa RPP dengan model pembelajaran berbasis proyek layak digunakan sebagai panduan atau pedoman oleh guru dalam proses pembelajaran. Perangkat pembelajaran yang dikembangkan dengan kategori layak dapat digunakan dalam pembelajaran fisika (Primadani, 2017). RPP yang dikembangkan terdiri dari 3 pertemuan dan menyesuaikan dengan sintaks model PjBL agar dpaat meningkatkan kemampuan komunikasi peserta didik. Penerapan pembelajaran menggunakan model pembelajaran berbasis proyek dapat meningkatkan kemampuan komunikasi peserta didik (Elisa et al. 2020). Hal ini perkuat oleh hasil penelitian Lestrai et al., (2016) bahwa pemberian model pembelajaran berbasis proyek dapat meningkatkan kemampuan komunikasi peserta didik.
LKPD yang dikembangkan masuk ke dalam kategori layak digunakan dalam prose pembelajaran sehingga dapat memudahkan peserta didik untuk mencari tahu dan menyelesaikan permasalahan melalui kegitan proyek dengan mengikuti prosedur pada LKPD. LKPD yang dikembangkan menyesuikan sintaks model pembelajaran berbasis proyek dan dirancang untuk mengetahui kemampuan tulisan peserta didik. Zulfa (2020) menyatakan bahwa LKPD mampu meningkatkan kemampuan komunikasi sains peserta didik. hal ini diperkuat bahwa LKPD dengan menggunakan model pembelajaran berbasis proyek dapat meningkatkan hasil belajar peserta didik pada konsep pemanasan global (Aristiadi et al. 2018).

Lembar observasi yang dikembangkan layak digunakan untuk menilai kemampuan komunikasi lisan dan tulisan peserta didik selama proses pembelajaran. Lembar observasi yang dikembangakn terdiri dari lembar observasi lisan dan tulisan. Indikator penilaian yang digunakan untuk lembar observasi lisan adalah pandangan mata, penyampaian informasi, bertanya atau menanggapi, pemahaman isi materi, dan penggunaan bahasa (Nugroho et al. 2019). Indikator untuk lembar observasi kemampuan tulisan terdiri dari kelengkapan, data, analisis dan kesimpulan, serta keindahan dan kerapian (Wangsa et al. 2017).

Lembar observasi untuk kemampuan lisan dan tulisan dirancang setiap pertemuan memiliki kriteria penilain masing-masing. Kriteria penilaian disusun berbeda karena menyesuikan dengan penilian yang diinginkan setiap pertemuan untuk mengetahui peningkatan kemampuan komunikasi lisan maupun tulisan peserta didik.

Angket respon mahasiswa diberikan kepada 20 mahasisa pendidikan fisika 
melalui google form. Perangkat yang diberikan kepada mahasiswa merupakan perangkat yang sudah divalidasi oleh validator ahli dan sudah direvisi sesuai saran yang diberikan. Respon mahasiswa menghasilan respon positif.

\section{PENUTUP}

Perangkat pembelajaran yang dikembangkan dalam penelitian ini yakni silabus, RPP dengan model pembelajaran berbasis proyek, LKPD, dan instrumen lembar observasi. Perangkat yang dikembangkan sudah divalidasi oleh validator ahli untuk menjamin kualitasnya sebelum digunakan dalam proses pembelajaran. Hasil valdiasi untuk keempat perangkat yang dikembangkan termasuk dalam kategori sangat valid sehingga layak digunakan untuk meningkatkan kemampuan komunikasi peserta didik. Mahasiswa program studi pendidikan fisika memberikan respon positif terhadap perangkat pembelajaran yang dikembangkan. Penelitian ini hanya dilakukan sampai tahap pengembangan yaitu validasi oleh validator ahli yang didukung oleh respon mahasiswa, sehingga untuk penelitian selanjutnya dapat melakukan uji coba langsung menggunakan perangkat pembelajaran ini.

\section{REFERENSI}

Aristiadi, H., \& Putra, R.R. 2018. Pengaruh Penggunaan Lembar Kerja Peserta Didik (LKPD) Berbasis Proyek Terhadap Hasil Belajar Peserta Didik pada Konsep Pemanasan Global. Biodusiana. 3(2), 77 - 84.

Elisa, C. E., Muharini, M., R., \& Hadi, L. 2020. Penerapan Model Pembelajaran Project Based Learning pada Pembelajaran Pemisahan Campuran unttuk Meningkatkan Keterampilan Komunikasi. Jurnal Pendidikan dan Pembelajaran Khatulistiwa. 9(1), $1-9$.

Gunawan. 2015. Model Pembelajaran Sains Berbasis ICT. Mtaram: FKIP UNRAM.

Kusumaningrum, S., \& Djukri, D. 2016. Pengembangan Perangkat Pembelajaran Model Project Based Learning (PjBL) untuk Meningkatkan Keterampilan Proses Sains dan Kreativitas. Jurnal Inovasi Pendidikan IPA. 2(2), 241-251.

Lestari, I. D., Leksono, S. M., Hodijah, S. R. N., \& Agustina, W. 2016. Pengaruh Penerapan Model Pembelajaran Berbasis Proyek (Project Based Learning) Terhadap Kecakapan Komunikasi Siswa Pada Konsep Biodiversitas. Jurnal Edukasi Matematika dan Sains. 5(2), 83-87.

Nugroho, A.T., Jalmo, T., \& Surbakti, A. 2019. Pengaruh Model Project Based Learning (PjBL) Terhadap Kemampuan Komunikasi dan Berfikir Kreatif. Jurnal Bioterdidik, 7(3), 50-58.

Primadani, R., Tukiran, T., \& Jatmiko, B. 2017. Pengembangan Pembelajaran Fisika Model Structured Inquiry untuk Meningkatkan Keterampilan Pemecahan Masalah Siswa pada Materi Fluida Statis. JPPS: Jurnal Pendidikan Sains. 6(1), 1235 1245.

Ratumanan, G. T., \& Laurens, T. 2011. Evaluasi Hasil Belajar Tingkat Satuan Pendidikan. Surabaya: UNESA University Press.

Setyani, N. D., Kartono, \& Suharno. 2016. Penngkatan Keterampilan Mengomunikasikan Melalui Penerapan Model Project Based Learning (PjBL). Didaktika Dwija Indria. 4 (9).

Sujana, G. A., \& Sopandi,P.H.W. 2019. Model-model Pembelajaran 
Inovatif Teori dan Implementasi.

Bandung: PT Rajagrafindo

Persada.

Wahyuni, I.P., Saputra, A., \& Harlita, H. 2019. Penrapan Model

Pembelajaran Project Based Learning untuk Meningkatkan Ketrampilan Oral Communication Peserta Didik Kelas X MIPA 4 SMA Negeri 5 Surakarta. Procending Biology Education Conference, 16(1), 65-100.

Wangsa, P. G., Suyana, I., Amalia, L., \& Setiawan, A. 2017. Upaya Meningkatkan Kemampuan Komunikasi dan Pemahaman Konsep Sisa melalui Pembelajaran Inkuiri Berbantu Teknik TSTS. Jurnal Wahana Pendidikan Fisika. 2(2), $27-31$.

Wirawan F., \& Mubarak, F.A. 2014. Kajian Teoritis Model Productive: Suatu Model Pembelajaran Fisika Berbasis Proyek yang Dikembangkan melalui Kegiatan Komunikatif. Jurnal Prosiding Pendidikan Sains, 1(1).

Zulfa, A. R. 2020. Pengembangan Lembar Kerja Peserta Didik (LKPD) Berbasis Think Talk write pada Tema Sistem Organ Manusia untuk Meningkatkan Keterampilan Komunikasi Sains di SMP N 1 Ponogoro. http://etheses,iainponorogo.ac.id/9 461/. 